\title{
Hovedbrud
}

\section{- mens vi gør feministiske forskningsstrategier i organisationer}

\section{Af Christina Hee Pedersen og EWA GunNARSSON}

Det er for langst slàet fast at organisationer er centrale for forbandling, forandring og reproduktion af konnede betydninger. Men bvilke centrale problemstillinger må man forbolde sig til, nair man forsker $i$ kon, organisation og forandring udfra et feministisk forandringsperspektiv?

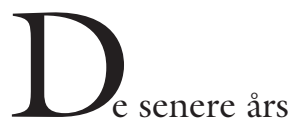

teori- og metodeudvikling $\mathrm{i}$ feministisk forskning udvider rammen for måderne, hvorpå vi, som feministiske organisationsforskere, kan forske i køns betydninger i organisationer. Det er især, som vi ser det, diskussionen om forskersubjektets produktive stilling i kundskabsproduktionen, som for sjældent inddrages i forskningsfeltet køn i organisationer. Men også bredere epistemologiske diskussioner, spørgsmålet om social forandring, diskussionen om relativisme og politisk relevans, er vigtige. En bevidst og systematisk forholden sig til disse udfordringer kan både nuancere og kvalificere de organisationsteoretiske spørgsmål, vi stiller som forskere (se f.eks. Acker 1999, Davies 1999, Gunnarsson et al 2003, Haavind 2000, Korvajärvi 1998, Widerberg 2002).

Vi vil i artiklen diskutere, hvilken betydning forskelle i position, interesser og forandringsforestillinger/ønsker har for de relationer, som bliver mulige at etablere i en forskningsproces omkring køn i en organi- 
sation. Det er specielt forskellene mellem forskere og praktikere vi vil se på, men vi vil også kort berøre forskelle i forholdemåder praktikerne imellem - noget der er indlysende, fordi vi arbejder med en så forskelssættende kategori som køn. De idealer vi bærer med os om at bryde med positivismens forståelse af kundskabsproduktion har ligeledes fremtvunget en stillingtagen til det, vi er kommet til at tale om som det uhensigtsmæssige makkerpar forsker/praktiker. Det har også bragt indledende refleksioner omkring forskersubjektets egen praktik i den interaktive forskning på banen.

Synet på forskeren som praktiker og subjekt indebærer nødvendigvis en langt større opmærksomhed på kontekstuelle betingelser, som også er forskerens. En pointe med artiklen er derfor også at antyde, hvorledes bredere samfundsmæssige udviklingstendenser skubber nye problemstillinger ind $\mathrm{i}$ forskningen om køns betydning i organisationer. Spørgsmål om forskydninger i forholdet mellem privat og offentlig, diskursive betingelser som omgiver ledelses- og organisationsudvikling, strukturændringer, normativitet, individualisering og forståelsen af politik og interesser, er alle meget brede kontekster, som kan synes langt fra den lokale organisatoriske kontekst, men som er pågående og indflydelsesrige i forhold til det enkelte organisationsmedlems praksis. Forståelser af disse forandringers gennemslag på et individuelt og interpersonelt niveau må inddrages langt mere aktivt og systematisk i vores analyser af køn, for at forstå de måder køn gøres på lokalt på en arbejdsplads. Men vel især for at diskutere om forskning i organisationer kan bidrage til social forandring af eksisterende kønsordninger. Til slut $\mathrm{i}$ artiklen vil vi kort berøre den betydning betingelserne for kundskabsproduktion i Akademia har for muligheden for den nødvendige nytænkning af de teoretiske og metodologiske tilgange til empirisk, interaktiv og forandrende forskningsprocesser indenfor forskningsfeltet køn i organisationer.
Det, som bevæger denne tekst, er et møde mellem to forskere og en fælles interesse for at kvalificere feministisk organisationsforskning. Dette mener vi blandt andet kan gøres via en kobling til det interaktive perspektiv. Vi har begge erfaringer med interaktiv forskning fra arbejdslivs-, bevægelsesog organisationsforskning. ${ }^{1}$ Det er en forskningstradition, der med sine eksplicitte ønsker om social forandring, uden større problemer kan forbindes med den feministiske forskningsinteresse for at ændre den eksisterende kønsordning. Forskellige feministiske retninger diskuteres i Lena Gemzöes bog "Feminism" (2002). Både den feministiske forskning og den interaktive forskning søger at styrke de 'demokratisk frigørende' processer i forskningen og i samfundet mere overordnet. Begge arbejder for en inklusion af flere og bredere livsområder i samfundsforskningen. Vore forskellige faglige baggrunde $\mathrm{i}$ arbejdsvidenskab og kommunikation har givet spørgsmålet om de relationelle aspekter på både mikro, meso og makro niveau en særlig plads. Det har ikke mindst været forbindelsen og den dynamiske relation mellem disse niveauer, som har haft vores interesse. Et fælles berøringspunkt mellem os er også at vores 'forskningsdrive' til stadighed næres af praksiserfaringer fra kvindebevægelsen. Vi ønsker ikke at fravige kravet om, at vores forskning skal give mærkbar mening for de mennesker, vi er i kontakt med i forbindelse med vore forskningsprojekter, selvom netop denne problematik er 'storproducent' af den type hovedbrud og spørgsmål, vi berører i artiklen. Før vi går over til behandlingen af de nævnte problemstillinger, vil vi præsentere de epistemologiske præmisser, vi skriver ud fra og de to forskningstraditioner, vi står midt $\mathrm{i}$.

\section{EN UDVIDELSE AF KUNDSKABSRUMMET}

Et epistemologisk ståsted som har et demokratisk frigørende forandringsperspektiv i centrum er blandt andet inspireret af femi- 
nistiske filosoffer som Minnich (1990). Det Minnich har fat i kan beskrives som en privilegeret gruppe hvide mandlige akademikeres videnskabelige tolkningsprivilegium, hvor $\operatorname{man}(\mathrm{d})$ på en dybt udemokratisk måde og i et ekskluderende kundskabs-'kapande' (-'afskærende') rum producerer, hvad der betragtes som almengyldig viden. Det, den feministiske forskning gør, er at åbne kundskabsrummet for kvinders livsvilkår og livserfaringer for dermed at skabe et mere demokratisk inkluderende kunskabs-'skabende' rum. På et overordnet niveau indeholder en sådan feministisk problematisering af den vestlige forståelse af viden et kritisk potentiale, ikke mindst i forhold til aktionsforskningens stræben efter det demokratisk frigørende i forskningen. Men opgaven med at inkludere løses ikke tilfredsstillende ved blot, som Minnich siger, at "add women and stir". At tilføre køn som en dimension er en mere gennemgribende øvelse. Den berører spørgsmål om, hvordan objektivitet forstås, og fordrer at der sættes grundlæggende spørgsmålstegn ved den forføriske, men også meget bekvemme, positivistiske forståelse af forskning som neutral, upolitisk og fri for følelser. Filosoffen Martha Nussbaum påpeger i hendes bog "Känslans skärpa och tankens inlevelse", at en vigtig kundskabsform er emotionaliteten, og at den er medproducent f.eks. i selve skabelsen af viden (Nussbaum 1992). Samme pointe udfoldes detaljeret på tværs af det store danske forskningsprojekt Køn i Akademia (Højgård og Søndergård 2004), og Simon Williams belyser $\mathrm{i}$ en af sine senere bøger, "Emotion and Social Theory" (Williams 2001), usynliggørelsen og manglen på refleksion, når det gælder om at forstå emotioners funktion og status $\mathrm{i}$ alt fra det epistemologiske niveau til den konkrete forskningsproces og forskersubjektets nødvendige refleksivitet. Også organisationsforskere har fat i denne glemte, men særdeles effektfulde dimension (Fineman 1993). I bogen "Känsla och regelverk i balans" problematiserer forskere og praktikere mere konkret de forskellige aspekter i 'emotionelt arbejde' i en forsikringsvirksomhed i forhold til erhverskompetencer, som skulle oversættes til et arbejdsvurderingssystem (Gunnarsson, Andersson och Westberg 1998). Feministisk forskning anerkender, at der findes forskellige kundskabsformer, og at dekonstruktion af etablerede syn på kundskab indebærer en yderligere udforskning af disse kundskabsformer og deres indbyrdes relationer.

\section{TO FORSKNINGSTRADITIONER}

Et feministisk perspektiv er per se skeptisk overfor de sammenhænge, hvor viden præsenteres som objektiv, kønsneutral og almengyldig, og det feministiske perspektivs fokus på magt tvinger ideelt set forskeren til at synliggøre, reflektere over og problematisere andre sociale magtordninger som f.eks. alder, etnicitet, seksuel orientering, klasse osv.. Sociale kategorier er virksomme i både organisationerne og $\mathrm{i}$ forskningsprocesserne, og de håndteres normativt af involverede aktører på forskellige måder. Det kritiske potentiale i kønsperspektivet ligger altså i, at det kommer til at fungere som en slags 'skærpet opmærksomhedsoptik', som synliggør forskellige former for magtrelationer.

Også den interaktive tradition stiller kritiske spørgsmål til grundlaget $\mathrm{i}$ traditionel positivistisk vidensopfattelse, som placerer forskeren $\mathrm{i}$ en privilegeret tolkningsposition, hvor forskeren bliver eksperten indenfor sit fagområde. Vidensproduktion som den oftest foregår i Akademia anses af begge retninger som alt for snæver, - ja som både ekskluderende og marginaliserende af vigtige vidensproducenter og vidensformer i samfundet.

Det er i visionen omkring forandring, demokrati og en frigørende forskningspraksis, at den interaktive forskning/aktionsforskningen og den feministiske forskning møder hinanden. Det som kan undre er, at de ikke i større udstrækning, hverken tidli- 
gere eller nu, mødes og inspirerer hinanden, på trods af at begge forskningsperspektiver på flere områder kunne have brug for gennemgribende diskussioner f.eks om noget så centralt i al kundskabsproduktion som forskersubjektets position.

I det interaktive perspektiv fremføres det, at praktikere og forskere i fællesskab kan generere en kvalitativ anderledes og mere 'demokratisk' baseret viden, og at den i bedste fald kan være frigørende for mennesker. Viden forstås som havende sine materielle rødder i menneskers hverdagspraksis. Men der er forskel på, hvilke sociale magtrelationer man vælger at fokusere på. Hvor den feministiske forskning tager fat $\mathrm{i}$ relationerne mellem og på tværs af køn, ligger der i aktionsforskningen et fokus på forsker-praktiker relationen. Denne forskningstradition understreger langt tydeligere end kønsforskningen, at de mennesker og de felter forskeren forsker i fra begyndelsen skal deltage i problemformuleringen af det, som oftest benævnes 'et fælles projekt.' Navet i forskningsprocessen i den kritiske aktions/interaktive forskning er det man gør sammen. Det man forandrer. Den fælles praksis.

Deweys beskrivelse af forskningens dynamik dækker en sådan måde at tænke forskning på: "Inquiery is cooperative human interaction with an enviroment; and both aspects, the active intervention with an evironment, and the cooperation with other human beings are vital". Jean Lave udtaler, da hun interviewes af Steiner Kvale “(....) that the only instrument that is sufficiently complex to comprehend and learn about human existence is another human being." (Kvale 1992).

Den stærke betoning af konstruktionen af 'det fælles' indeholder, som vi ser det, et stort og produktivt potentiale i forskningsprocessen. Menneskelig kontakt og kommunikation bliver central og sådanne bestræbelser giver god mening i et historisk øjeblik, hvor fællesskaber smuldrer. Men tanken om det fælles projekt kan samtidig lægge 'et naivt slør' henover den nødvendige problematisering af magtrelationer mellem og indenfor kategorierne forskerepraktikere. Det er netop i forhold til magtdimensionen den største kritik af aktionsforskningen er formuleret, og den er i høj grad også formuleret fra feministisk hold.

Kønsforskningens fokus på magtrelationer mellem køn skærer lige ind til benet $i$ begge kategorier. Både forskeren og praktikeren må forholde sig til sig selv som køn og den proces fremtvinger en anderledes problematisering af forskersubjektets sociale position, end den man kender fra den interaktive forskning. Det gælder specielt, når man tager fat på problematikken "fælles og/eller forskellige interesser". Diskussionen om, hvorledes man bør forstå kønnenes fælles erfaringer og interesser, har historisk været en central teoretisk diskussion i kønsforskningen. Parrallelt med diskussionerne om det fælles er diskussionerne om forskelle indenfor og mellem katergorierne 'kvinder' og 'mænd' blevet ført (se f.eks Harding 1992, West and Fenstermaker 1995). I firsernes analyser stod klasseskel mellem kvinder i fokus, men også forskelle mellem forskere og praktikere blev diskuteret på det tidspunkt. Forenklet kan man sige, at bevægelsen er gået fra et standpunktsteoretisk synspunkt til et mere nuanceret og relativiseret syn på forskelle (Kvande 2003, Thurén 2003). Det er en position, som også synliggør variationer indenfor en lang række andre sociale kategorier. Thurén har gennem sin udvikling af kønsdimensionens forskellige aspekter: styrke, rækkevidde og hierarki tilført en værdifuld kontekstbunden nuancering (Thurén 1996). Dominansen af poststrukturalisme i de senere års kønsforskning gør diskussionerne omkring politisk handling og spørgsmålet om interesseforskelle, politiske strategier og alliancer trænger sig på (Harding 2004, Eduards 2002).

I forhold til den interaktive tilgang til forskning står feministiske forskere $\mathrm{i}$ et dilemma, ved at hovedfokus her lægges på 
den lokale vidensproduktion og forandringer på et lokalt niveau. Det feministiske mål er jo netop gennemgribende samfundsforandringer.

Både ønsket om at udvide kundskabsrummet og den centrale politiske diskussion omkring interessesammenfald og -forskelle indebærer, som vi ser det, at organisationsforskeren må inddrage sin egen praksis og position i vidensproduktionen som et dynamisk aktiv i forskningsprocessen. At synliggøre en social magtordning som køn kræver, at naturaliserede/etablerede begreber, som også forskersubjektet selv bærer med sig, sættes under lup.

\section{INDDRAGELSE AF FORSKERSUBJEKTET}

At inddrage forskersubjektets betingelser i vidensskabelsesprocesserne som en kontekst, der skal bearbejdes, reflekteres og forstås systematisk, er en praksis, som i sig har indbygget mulighederne for at give større indsigt i den eksisterende kønsordning og $i$ andre sociale magtordninger. Men det er samtidig en dekonstruktion som kan opleves meget konfronterende, og i høj grad en proces som indebærer, at den enkelte forsker placerer sig selv i en risikofyldt position i forhold til specielt legitimiteten i eget felt: forskersamfundet. Hvis vi ikke skal falde i samme fælde, som de videnskabsteoretiske traditioner vi kritiserer, mener vi dog, som mange andre især feministiske forskere, at det er vigtigt at tage denne udfordring op. Også fordi det, som vi ser det, giver en langt bedre baggrund for at kunne producere demokratisk inkluderende kundskab (se f.eks Davies 1999, Haavind 2000, Skeggs 1997 Widerberg 1999 og 2002).

Den forsker som ønsker at bidrage til at opbygge en ligeværdig dialog omkring køn med en organisations medlemmer, kommer nemlig uvægerligt til at stå i en lang række dilemmaer omkring sin egen position, egne interesser og egne forestillinger om forandring. Og hvis det er dialogen og kontak-

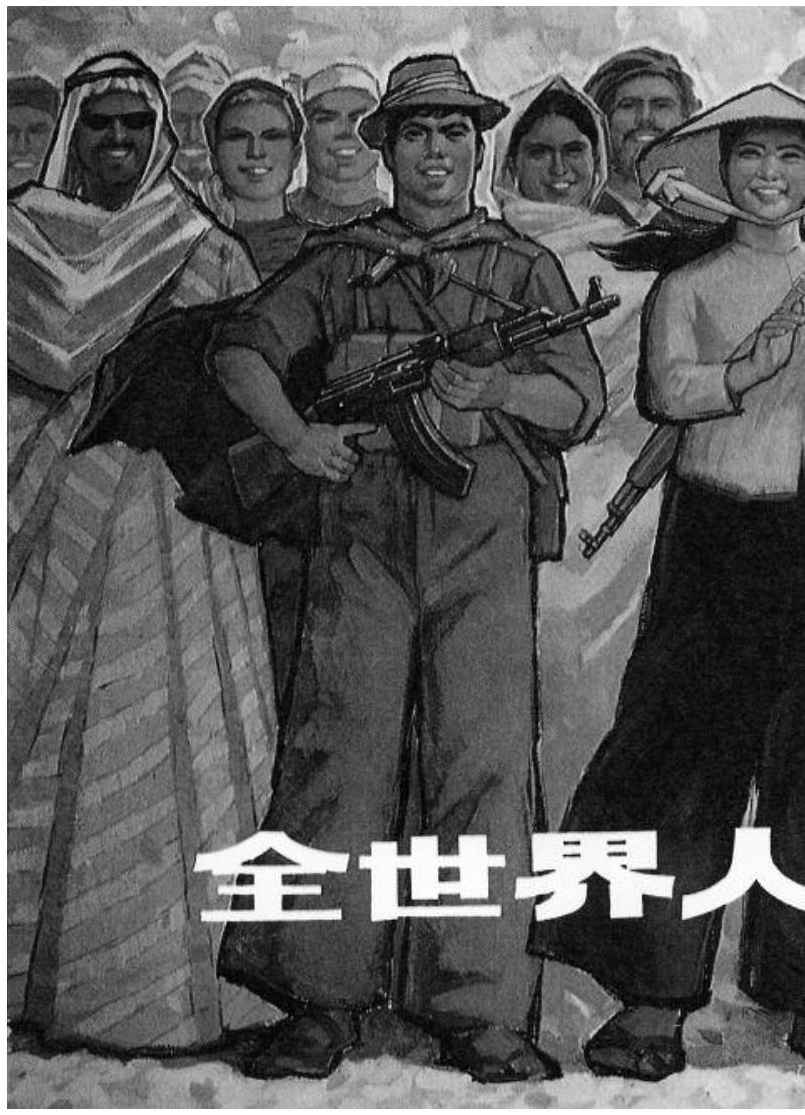

ten med folk uden for universitetet, som gør forskning til en meningsfyldt aktivitet, fordrer det dialogiske ideal en synliggørelse af forskerpraktikeren, som deltagende praktiker. Forskerens handlinger inddrages ikke i analysen med navlepilleri til formål, men for at kvalificere forskningen. Forskerens deltagelse i de organisatoriske rum, som en besøgende, er nemlig en levende dimension i forskningsprocessen.

En forskers til- og fravalg er i bevægelse hele tiden. Disse til og fravalg præsenteres ofte som bevidste velreflekterede valg i en overbevisende logik og som en afspejling af forskerens kompetencer og kvalitet. Det er dog ofte sådan, at vi konstruerer og rekonstruerer disse historier om til- og fravalg 


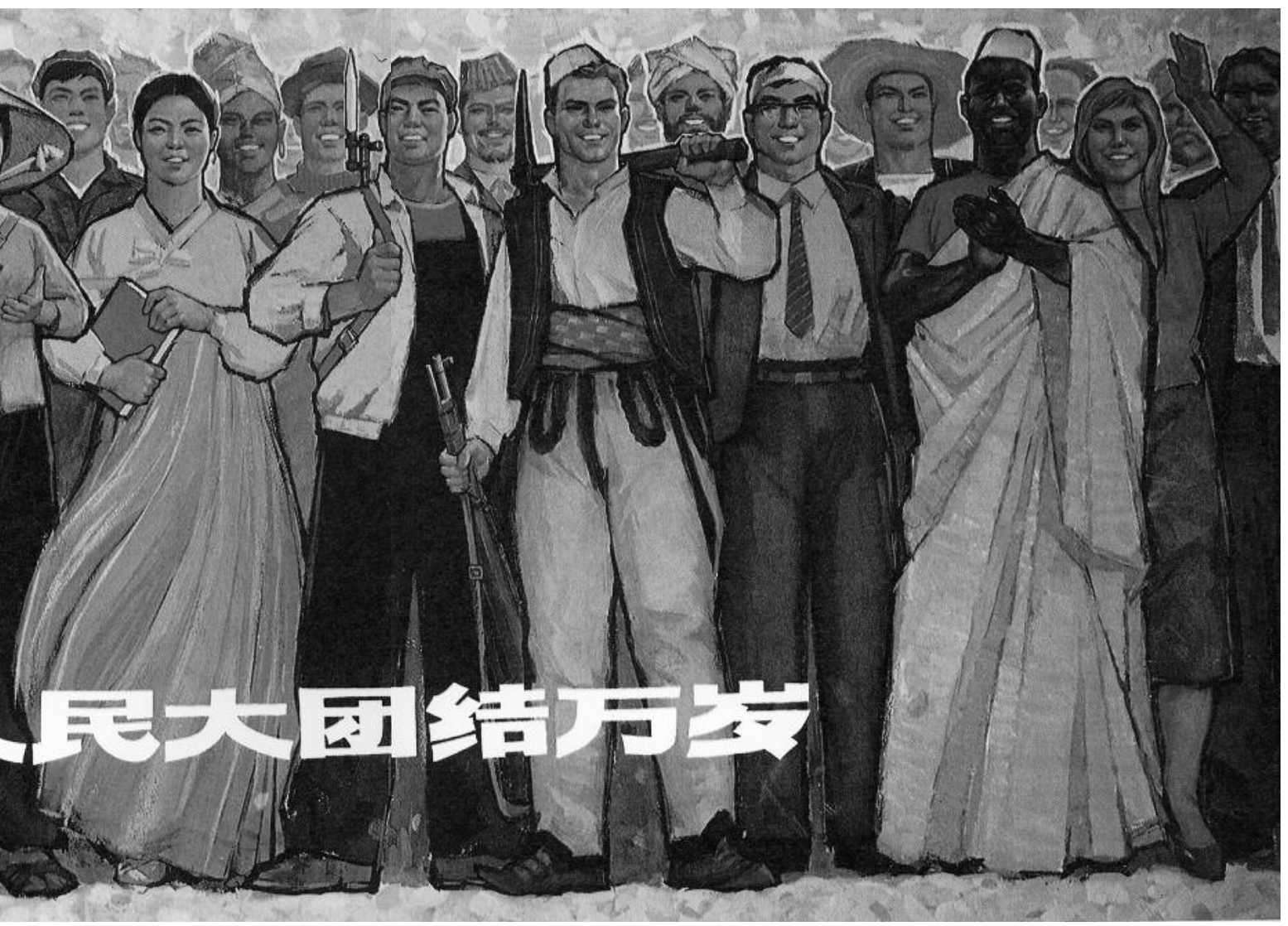

"Lange leve verdens forenede folk", Finn Suenson Forlag, 1978 
mange gange i løbet af forskningsprocessen. De kontekstuelle betingelser som omgiver og gennemsiver en konkret lokal situation, hvor man f.eks tager kontakt til en organisation, bliver altafgørende for, hvilke handlinger det derefter bliver muligt at udføre. Forhandlinger, kompromisser og politiske magtforhold former forskningsbetingelserne, hvorfor de naturligt bør medreflekteres, ikke som et bias, men som betingelser, der kan lære os noget om den virkelighed, vi konstruerer viden i og omkring sammen med andre. 'Magt' og dens kompagnon 'afmagt' er af afgørende betydning i den normative proces, det er at give både vores forskningspraksis og vore kundskabstilbud legitimitet.

Pointen er her, at forskerens interaktion med organisationen kan synliggøre vigtige karakteristika ved organisationens kulturog legitimeringspraksisser, som det kan være ganske svært at fă adgang til gennem f.eks et interview. I et eksempel fra et projekt om køn i bistandsorganisationer i Danmark blev det udfordringen overhovedet at få adgang til et ministerium. Efter næsten ti måneders løbende kontakt med ministeriets tre kønsansvarlige (alle kvinder), som var blevet bedt om at invitere fire kvinder og fire mænd til en tre timers workshop, måtte seancen aflyses en time inde i workshopforløbet, da halvdelen af deltagerne alligevel ikke havde tid til at deltage, men havde mere påtrængende opgaver at løse, som de følte sig tvunget til at prioritere (Pedersen 2004). Det var de mandlige deltagere som stod af midt i seancen. Således vil en eller flere forskeres erfaringer fra de tager kontakt til et felt kunne sige noget om feltets forhold til sin omverden og organisationens forholden sig til genstandsfeltet køn, - ikke i politikformuleringerne, men i praksis. En aktionsforskningsinspireret forholdemåde vil altså kunne pege på meget vigtige forhold omkring køn i organisationer, som inviterer til analyse, og som man måske ikke ellers ville have fået øje på.

Et andet argument for at praktikere, som deltager i et forskningsprojekt, kan få stor glæde af, at forskeren medreflekterer sin egen position og praksis, sine dilemmaer og kønnets betydning for både position og legitimitet, er, at de her får adgang til et andet felts (det akademiske) produktionsbetingelser, men også får en mulighed for at forstyrre deres billeder af, hvad forskning er og skal kunne. Ofte mødes forskeren af praktikere med meget faste forestillinger om viden som fakta, der kan orientere og inspirere deres praksis. Forenklet kunne man sige, at det forventes at forskeren skal levere varen, altså den nye og efterspurgte viden i en anvendelig form, og så skal praktikerne nok konsumere den i forhold til den virkelighed, hvor de er eksperterne. Den interaktive forsknings epistemologiske ståsted udfordrer og udvider en sådan vidensforståelse og sætter spørgsmålstegn ved den klassiske relation og grænsesætning mellem producent og forbruger af viden. Det kan virke provokerende, specielt fordi mennesker i organisationer i dag er meget pressede på tid, at blive inviteret med ind $\mathrm{i}$ analyseprocessen (det er jo forskerens job!), ligesom indsigter i forskersamfundets legitimerings- og magtrelationer nok kan ryste forestillingerne om objektivitet og fakta. En sådan dekonstruktiv forholdemåde baner vejen for interaktive demokratiserende forskningsprocesser i organisationer. En forsker, som tør medreflektere disse processer, udvider de kundskabstilbud, hun eller han præsenterer sine samtalepartnere og/ eller læsere for. ${ }^{2}$ Schratz og Walker (1995) beskriver dynamikken som den leves i kommunikationen mellem forskerpraktiker og et felts praktikere: "Research" we suggest is not a technical set of specialist skills but implicit in social action and close to the ways in which we act in everyday life. We find increasingly that the worlds of academic and social life, theory and practice, work and family are not really so different, but constantly interrupts one another, often in complex ways."

Afstanden, mellem den diskurs vi som 
forskere trækker på og vore egne praktikker - 'the gender we think and the gender we do', som Silvia Gherardi udtrykker det (Gherardi 1995), er en ligeså relevant problematisering af feministiske forskeres egne kønnede forestillinger og praktikker, som det er en analysevinkel, vi kan forstå data med, og som kan diskuteres med organisationsmedlemmerne i forskningsprocessen.

Man kan f.eks. med god grund spørge os, hvilket syn på ligestilling og social forandring vi fører med os ind i forskningen, hvad det indebærer for, hvad vi fokuserer på og kan se, og hvordan vi kommunikerer med praktikere omkring vore egne forståelser og utopier, specielt hvis vi kan mærke, de er meget forskellige fra de andre deltageres? En frugtbar metodologisk tilgang som synliggør forskersubjektets egne forestillinger, er udviklet af Widerberg (1999 og 2002), hvor hun på forskellig vis anvender erindringsarbejde som analytisk greb. Men denne problemstilling, mener vi, er alt for lidt problematiseret og alt for usynlig ikke bare i de kundskabstilbud, vi som forskere kommer frem med, men også i de levende dialoger i kønsforskningssammenhænge og i forskningsprocessen i organisationerne. Men her ligger debatpotentialet, her ligger en produktiv konflikt, her ligger læring og kønspolitik!

\section{FORSKELLIGE NORMER OMKRING RELEVANS, FORSKELLIGE \\ BEVÆGGRUNDE FOR DELTAGELSE}

Når den feministiske og interaktive forsker er på vej ind i en organisation, skal hun kunne overbevise andre om, at deltagelsen $\mathrm{i}$ forskningsprojektet vil kunne føre noget positivt med sig. Hun eller han har højst sandsynligt et anderledes syn på viden, er proces- og ikke resultatorienteret og kan sjældent forudse eller konkretisere de resultater, forskningen vil generere. Man kan sige, at forskerens epistemologiske ståsted grundlæggende vil blive udfordret af praktikernes forestillinger om, hvad produktion af videnskab er, og hvad videnskab skal kunne. Evnen til at overbevise andre om, at det ikke-kendte og det ufærdige er relevant og positivt, bliver alfa og omega for, om det bliver muligt at indgå i en demokratisk dialog og en demokratisk forholdemåde med praktikere i en organisation. I processen med at opnå ekstern finansiering, men også med at finde vej ind i en organisation, bliver forskerens evner til at sælge sin idé derfor central. Forskeren skal nemlig, udover at kunne forhåndsgarantere processens anvendelighed, overbevise om køns relevans som tema og for sin egen forsknings skyld sikre engagement og vedholdenhed hos deltagerne i forskningsprocessen. Det fordrer en udviklet evne til at opbygge tillid på meget kort tid, men det betyder også, at forskeren forstår at bevæge sig i en meget normativ organisatorisk kontekst!

Organisationens normsæt og den enkelte medarbejders strategier i relation til hendes eller hans plads i organisationshierarkiet vil præge måden, folk er til stede på i organisationen, og vil derfor også præge, den måde man 'vælger' at deltage i et eventuelt forskningsprojekt på. I alle organisationerne kæmper medlemmerne om opmærksomhed og anerkendelse. I forhold til en sådan kamp betyder det meget, hvordan et projekt bliver lanceret i organisationen og hvilken opbakning forskningen får, - og især fra hvilke personer.

Den øgede individualisering påvirker den enkelte medarbejders opfattelse af sig selv, ligesom den påvirker forholdet til kollegerne. Skønt individualiseringen som socialt fænomen uden tvivl udtrykker sig forskelligt fra branche til branche, ser vi dog en generel tendens til, at fællesskaber på arbejdspladser er under pres, er sporadiske eller helt opløst. Det betyder ofte, at det er den enkelte og ikke grupper, som skal tage stilling til, om de vil deltage i et forskningsprojekt.

Den relation, forskeren etablerer til den øverste ledelse, men også den nærmeste leder betyder altså noget for forskningspro- 
cessens forløb og forskerens råderum, samt for den synlighed forskningsprocessen har $\mathrm{i}$ det tidsrum forskeren er i organisationen. $\mathrm{Og}$ relationen mellem forsker og leder vil påvirke den enkelte medarbejders lyst til/ mulighed for at deltage.

Om køn som tema opfattes som noget godt, statusgivende eller tabuiseret, åbner og lukker forskerens handlerum. Den normativitet som er forbundet med kulturelt bundne køns- og kundskabsopfattelser bæres ikke bare af organisationens praktikere, men også af forskerne. Der er brug for langt større selvrefleksivitet her, som kan synliggøre, hvordan forskellige positioner rangordnes i både forskerens og praktikernes hoveder, mens der forskes.

\section{HVEM EJER PROBLEMFORMULERING OG PROCES - GRANSER FOR DELTAGELSE?}

Den interaktive forskning fungerer som en katalysator for øget dialog og fælles refleksion, men udvikler sig samtidig ofte til dilemmaer for forskersubjektet, fordi han eller hun făr virkeligheden og de betingelser, som omgiver praktikerne, lige op i ansigtet. At lave deltagerorienteret forskning er ikke kun et spørgsmål om at få nogle praktikere til at deltage $\mathrm{i}$ et forskningsprojekt, men derimod en proces, som kræver mange og tidlige teoretiske, metodologiske og strategiske overvejelser og beslutninger omkring et projekts formål, ressourcer og forandringshorisont. Specielt hvis deltagelse skal kunne forbindes med ejerskab til processen. Har man et deltagerorienteret udgangspunkt, må man tage stilling til disse grundlæggende spørgsmål, når kontakten etableres til et praksisfelt udenfor universitetet og i forbindelse med udviklingen af selve forskningsdesignet. De valg som foretages ved forskningsprojektets start, får nemlig konsekvenser for samtlige deltageres bevægelsesmuligheder under og efter, at det er afsluttet.

Her er blot et lille udvalg af spørgsmål, som man som forsker nødvendigvis må for- holde sig til: Hvem har tid, lyst og ressourcer til at deltage i forskningsprojektet? Hvilken type forandring gives der adgang til, hvis kontakten går gennem en organisations øverste ledelse? Hvilken, hvis det er de menige medlemmer i organisationen eller fagforeningen inviterer forskeren ind? Hvad og hvem giver forskningen legitimitet? Hvilke forandringer arbejder forskeren for, og hvilke forandringer er vigtige for deltagerne? Hvem ejer forskningsresultaterne, og hvordan må forskningen formidles til forskeroffentligheden og den brede offentlighed?

Her vil vi koncentrere os om spørgsmålet om ejerskab til et forskningsprojektets problemstilling. En grundtanke i aktionsforskningen er, at problemformuleringen i et interaktivt forskningsprojekt skal foretages sammen med praktikerne. Aktiv deltagelse og engagement ses som en forudsætning for en meningsfyldt forskningsproces. Eksempler fra vore egne forskningsprocesser kan illustrere de mere principielle (og meget konkrete) problemstillinger, forbundet med en central tanke $i$ den interaktive forskningstradition, nemlig spørgsmålet om, hvem der ejer problemformuleringen.

Inokon $^{3}$ er et pågående integrations og kompetenceudviklingsprojekt i en videnstung organisation i Sverige, en organisation med rødder i en positivistisk/teknisk naturvidenskabelig kundskabstradition. Det har to hovedformål, a) at styrke ligestillingsbestræbelserne i organisationen og b) at styrke de videnskabelige kompetencer i forhold til kønsforskning, gennem at søge at synliggørekønsperspektivet i policy tekster og publikationer, som udgår fra organisationen. Projektet har en interaktiv forskningstilgang, som prioriterer et nært samarbejde mellem forskere og praktikere. En gruppe af femten såkaldte 'forandringspiloter' skal efter planen skabe forskellige forandringsog læringsprocesser i organisationen de tre år projektet står på. Modellen med interne forandringspiloter blev valgt som strategi, for at sikre en mere bæredygtig foran- 
dringsproces, og for at modvirke de interne kræfter i en organisation, som altid findes og som modarbejder forandringstiltag og ønsker at fastholde den eksisterende kønsordning.

For at kunne opbygge en fælles viden om køn afholdt man i starten forskellige seminarer, for både de femten forandringspiloter og for hele personalegruppen. Fokus på disse seminarer lå på lærings- og forandringsprocesser, som skulle styrke integrationen af ligestilling i organisationen og de ansattes kønsvidenskabelige kompetencer, f. eks i forhold til forståelsen af deres egen organisation, udviklingen af policy-dokumenter, samt i bedømmelsen af kvalifikationer i ansættelsesprocedurer.

Den fælles problemformulering med praktikerne fandt først sted i forbindelse med afrapporteringen af den kortlægning af organisationen, som forskerne tidligere havde lavet uden praktikeres direkte deltagelse. Det var en organisationskortlægning, hvor både rammer og indhold fra begyndelsen var forskerdefinerede, men selvfølgelig påvirkede af interview foretaget med forandringspiloterne om organisationen. Et mere interaktivt perspektiv ville have haft et anderledes design. Hvis forskere og forandringspiloter indledningsvis sammen havde formuleret problemerne omkring organisation, ligestilling og kompetencer havde problembilledet højst sandsynligt set anderledes ud, og de aktiviteter man valgte at gå i gang med havde måske været anderledes. Problemformuleringen ville da tydeligere have vist forandringspiloternes oplevelse af organisationen, og disse ville have kunnet bruges aktivt i forandringsprocessen af både praktikere og forskere. Problembilledet ville da også i højere grad have tvunget forskerne til at orientere sig i organisationens selvforståelse, og måske have bevirket en anderledes forholdemåde i organisationen. Det mener vi, ville have givet et bedre udgangspunkt for at sikre ejerskab til både problemformulering og forandringsproces, i stedet for at energien først og fremmest udsprang fra en gruppe engagerede forskere.

I ovenstående eksempel kom den forskerproducerede kortlægningsrapport til at fungere som en kilde til en meget dynamisk diskussion, som gav forskerne en ny forståelse af organisationens selvbillede, og som resulterede $i$, at forskellige jobkategorier og forståelser af disse ud fra et kønsperspektiv blev indflettede i det endelige dokument. Køn og position blev på den måde gjort meget tydelige.

En måde at have håndteret Inokon projektet anderledes på havde været at have haft en reflekterende workshop inden problemformuleringsfasen, hvor den enkelte medarbejder kunne have arbejdet aktivt med egne kønsforestillinger og sammen med andre reflekteret over de frlles udtryk køn havde i deres organisation. Forandringspiloterne kunne have gjort ligeså, hvorefter man kunne have udviklet et fælles design for den kommende forskningsproces. Dette ville have givet et bedre og mere forankret grundlag for tilrettelæggelsen af det kommende kursus i kønsvidenskab, både når det gjaldt form og indhold.

Forandringspiloterne var mere passive under den første fase, end hvis forskerne havde overladt dem ejerskabet mere tydeligt fra starten. Deres position blev forandret på en workshop, hvor forskerne satte fokus på aktiv deltagelse, og på, hvad det indebærer at være forandringspilot med køn i fokus. De to forskere, som havde befundet sig i organisationens daglige praksis, trak sig samtidigt fra den daglige praksis, og det betød, at forandringspiloterne i højere tog processen på sig, og ikke lagde ansvaret over på forskerne. ${ }^{4}$

I forskningsprojektet om køns betydning i danske bistandsorganisationer viste det sig hurtigt, at det blev meget svært overhovedet at få folk til at deltage, specielt at få en gruppe til at følge projektet over tid. En bærende idé i projektdesignet var deltagelse. En aktiv dialoggruppe bestående af mænd og kvinder repræsenterende tre typer 
af aktører i den danske bistandsverden (Ngo, stat og private konsulentvirksomheder) skulle samles tre eller fire gange over en periode på halvandet år for at diskutere projektets empiri med de to forskere. Halvtreds invitationer blev sendt ud for at fà en gruppe på ti til tolv mennesker til at melde sig. Til det første møde mødte ti deltagere op, hvoraf de to var mænd, til de to følgende var der seks kvindelige deltagere tilstede.

En af grundene til at det blev svært at få dialoggruppen til at fungere var, at organisationernes medlemmer hverken havde tid eller ressourcer til at deltage i eksterne, deltagerorienterede forskningsprojekter. Adgangen til og kontrollen over ressourcer i disse organisationer etablerede betingelserne for, hvilke dele af det deltagerorienterede metodedesign som det blev muligt at gennemføre. Økonomiske ressourcer og tid som en ressource skulle vise sig at blive en nøgleproblemstilling i projektet også i forhold til andre aktiviteter i projektet. Det pres den enkelte medarbejder oplevede i forhold til sit eget fagområde, f.eks. i forhold til målorientering, produktudvikling, styring og afrapportering og det ene organisationsudviklingstiltag efter det andet, fik mange til at sige fra overfor at deltage i et forskningsprojekt. Der blev talt direkte om kroner og ører og om både halve og hele timer, når adgangen til organisationerne blev forhandlet på plads. Her bliver spørgsmålet om, hvilke organisationer organisationsforskningen overhovedet har adgang til påtrængende, for er det sådan, at det er helt specifikke organisationstyper, som i disse år leverer de empiriske data til organisationsforskningen?

\section{FORSKELLE I FORSTÅELSER AF KØN}

I samarbejdsprocessen og i arbejdet med at få adgang til en organisation som forsker er der utroligt mange sammenstød, som lever i det skjulte. Både forsker og organisation vil, når de skal beskrive et forskningssamarbejde, læne sig op af en mainstream-diskurs om de mange fordele der er ved videndeling og erfaringsudveksling, men de konkrete samarbejdssituationer indeholder mange momenter, hvor interesseforskelle støder sammen og afslører, hvor politisk en proces interaktiv, feministisk forskning, og kundskabsproduktion i det hele taget, er. Det, som umiddelbart virker attraktivt for en organisation og specielt ledelsen at engagere sig i, er forskningsprojekter, som stiller brugbare konkrete resultater i udsigt. Det forventes, at den viden forskeren producerer, skal kunne omsættes til praksis uden for mange anstrengelser og ressourcekrævende formidlingsindsatser. Sådan er kønsforskning sjældent.

Vores erfaring fra organisationsforskningen er f.eks., at der ofte findes meget forskellige forståelser af køn mellem forskere og praktikere, men altså også i nogle tilfælde praktikere imellem, og at disse forskelle betyder meget for relationen og kommunikationen i forskningsprocessen. Forenklet kan man sige, at langt de fleste kønsforskere privilegerer forståelsen af køn som social konstruktion, hvorimod mange organisationers og praktikeres syn præges af et essenspræget kønssyn og taler om iboende mandlige og kvindelige egenskaber, som man bør tage hensyn til. Forskelle i måder at forstå køn på vil få forskellige konsekvenser for forståelsen af, hvilken type handlinger, som vil fore forandring af eksisterende kønsrelationer i organisationer med sig. Synet på køn og ligestilling kan skifte, hvis praktikere fra forskellige niveauer i en organisation deltager, og da kan spørgsmålet f.eks. komme til at handle om social klasse og om, hvordan køn og social klasse interagerer med hinanden. Her er forskerens egen sociale placering i spil og udfordringen at bevæge sig selvkritisk og selvrefleksivt i relation til sit felt. Derfor fremhæver vi også her, hvad der måske kan forekomme som meget grundlæggende og indlysende metodologiske spørgsmål, som dagsaktuelle og spørgsmål den feministiske forsker må tage op igen og igen. 
Hvilke udfordringer står man overfor, når man ønsker at arbejde med køn ud fra et interaktivt og dermed demokratisk befordrende perspektiv og forskelle i interesser og perspektiver er fremtræedende? Hvad stiller man som forsker op, hvis praktikerne eksempelvis slet ikke interesserer sig for at arbejde med køn eller for at forholde sig eksplicit til maskulinitet? Hvordan kan man som interaktiv forsker med et demokratisk perspektiv for øje få køn på dagsordenen i dialogerne, hvis man møder lukkethed? Og hvilke forskningsstrategier skal forskeren vælge, hvis kun enkelte kvindelige praktikere i organisationen har en interesse $i$ at synliggøre, diskutere og forandre de eksisterende normer omkring køn i deres organisation? Hvordan udvikles ejerskab til processen, hvis samtlige involverede kæmper mod at synliggøre maskulinitets betydning for organisationsudvikling, - og derfor ikke har lyst til at deltage?

Rikke Randorff Hegnhøj kommer i sit speciale "Mellem konsensus og krise" med en række gangbare og meget konkrete bud på, hvordan man kan håndtere dette dilemma i en postmoderne samtid, hvor kønnet leves et sted mellem konsensus og krise. Hun viser, hvorledes mænd og kvinder i den organisation hun undersøger forstår og praktiserer køn som paradoksal og ambivalent, og hun konkluderer at det er i spændingen mellem køns relevans og samtidige ikke-relevans at den defensive kønsneutrale diskurs, som mange organisationsforskere disse år identificerer, kommer til syne (98). Hegnhøj arbejder med en eksplicit feministisk forandringsdagsorden i sit projekt, og kommer dermed også til at forholde sig meget konkret metodisk til spørgsmålene om, hvordan man, med interaktive idealer, kan tale med mennesker om noget de forstår som ikke-relevant og ikke problematisk. Hvorledes, spørger hun, kan man bede folk om at forholde sig til faktorer, de ikke mener, eksisterer? Hvordan kan jeg legitimere min undersøgelse overfor deltagerne, når de finder det irrelevant og uinteressant at tale om? I processen med at finde ud af, hvordan hun skal positionere sig og kommunikere i denne kontekst, arbejder hun aktivt med de krav til sig selv som forskeren som hvert af de ovenstående spørgsmål generer (Hegnhøj 2004, 31 ).

Hvis idealet om social forandring og demokratiske relationer tages alvorligt, skal forskeren turde gå i dialog med praktikerne omkring disse. Hun skal turde præsentere egne ideer og ståsteder og møde praktikernes forestillinger om køns betydning. Som feminist bør hun ligeledes kunne lægge egne position er, som kritiserer de eksisterende kønsforestillinger og praksisser, klart frem. I både Danmark og Sverige er det svært at tale om maskuliniteter som sådan (Hearn 1994), men også det at tale om kvinder, som kvinder kan generere modstand, i hvert fald i Danmark (Hee Pedersen 2000, Hegnhøj 2004). Der er altså en diskursiv kontekst, som inkluderer og ekskluderer visse temaer og en betragtelig del af de temaer, som interesserer den organisationsforsker, som arbejder med køn, er ekskluderede.

I takt med den aktuelle tabuisering af kønsperspektivet i Danmark har det metodologiske argument om, at man ikke nødvendigvis skal spørge til køn, eller lægge sin feministiske interesse frem, for at diskutere dem aktivt med praktikerne, vundet indpas. Denne strategi kan naturligvis anvendes, men er svær at godtage fra en position, hvor man ønsker at fremme medforskerperspektivet og den demokratiske deltagelse. ${ }^{5}$ Den interaktive forskning er kendetegnet ved ønsket om at opbygge lige og gensidige relationer mellem forskere og praktikere udfra det grundsyn, at forskere og praktikere har forskellige roller og interesser i den fælles kundskabsproduktion, hvor begge parter er aktive deltagere i skabelsen af teoretisk og praktisk anvendelsesorienteret viden (Svensson m.fl. 2002, 11).6

Forskersynlighed i kommunikationen indeholder også det centrale spørgsmål om, hvilket syn på social forandring vi som fe- 
ministiske forskere fører med os ind i forskningen. Hvad indebærer vores position for, hvad vi fokuserer på, og kan se, og hvordan vi kommunikerer med praktikere omkring vore egne forståelser og utopier, altså specielt hvis vi kan mærke, de er meget forskellige fra de andre deltageres. Her kunne design med inviterede eksterne forskerblik på vore forskerpraksisser være et innovativt og udfordrende bud på en selvrefleksiv forskerpraksis.

\section{HOVEDBRUd HOS FORSKERSUBJEKTET}

Vores erfaringer fra forskning om køn i organisationer viser, at vore hensigter om at fastholde en klar forskerposition overhales af virkeligheden. Rigtig mange gange foretager forskeren et væld af kompromisser og reformuleringer, som bevæger projektet og som får konsekvenser for den kommunikation og de relationer, som etableres. Man kan udtrykke det sådan, at forskerens egne til- og fravalg, samt de valg og kompromiser som indgås mellem forsker og forskningsfelt, er medskabere af forskningsbetingelserne på en kaotisk og kompleks måde. Sådanne betingelser bør naturligvis medreflekteres, ikke som et bias, men som betingelser der samtidig kan lære os noget om den virkelighed, vi konstruerer viden i og omkring, - i interaktiv forskning, sammen med andre. De konkrete handlinger, man mere eller mindre velovervejet foretager sig i forskningsprocessen, befinder sig i en konstant bevægelse og magt er altid involveret $\mathrm{i}$ de valg, som foretages. Magt er central i den normative proces, det er, at give både forskningspraktisser og kundskabstilbud fra det akademiske felt legitimitet.

Der er et behov for mere systematisk at gå i kødet på den type hovedbrud, som specielt det interaktive element skubber i forgrunden. Hvilke metodologiske greb griber vi ud efter, når vi føler os usikre? Hvilke begreber tænker vi relationen forsker/praktiker i? Og hvad gør disse begrebsforestillinger ved vores forholdemåder i forskningsprocessens forskellige faser? Hvilke ord og begreber præsenterer vi os selv med i en organisation? Hvordan forholder vi os selv til autoriteter i organisationer og kønshierarkier? Hvordan gebærder vi os kropsligt og sprogligt mellem forskellige hierarkiske positioner i en organisation? Hvad betyder vores egne akademiske organisations legitimeringsprocesser for vore tilog fravalg? Og ikke at forglemme: Hvordan gør vi henholdsvis den mandlige og kvindelige organisationsforsker, der forsker i køn, og hvilke konsekvenser har vores kønnede udtryk for den kontakt, det bliver muligt at skabe med forskellige medlemmer i organisationen?

\section{SAMFUNDSBETINGEDE FORANDRINGER I ARBEJDSLIVET - DET GRÅDIGE ARBEJDSLIV SOM KONTEKST}

De samfundsmæssige forandringer i arbejdslivet udfordrer idealerne om dialog og demokratisk deltagelse i forskningsprocessen og de genererer en stor del af de spørgsmål, vi har taget fat i i det ovenstående. De er vigtige kontekster i forskningsprocessen, kontekster som strukturerer de relationer, som etableres og de kundskabstilbud, det bliver muligt at fremkomme med.

Ord og begreber fra, hvad der tidligere blev betragtes som privatsfæren, bringes ind i virksomhederne. Den efterhånden allestedsnærværende værdibaserede ledelse bygger på en håndfuld værdier, hvoraf mange af dem er hentet fra 'privaten' fra omsorgskategorier eller fra kategorier som regulerer social adfærd. At tænke på sit firma som en familie, man elsker og har et ansvar for, er en metafor, mange medarbejdere i organisationer er blevet præsenterede for. Bourdieu taler om de forskellige myter som ledsager samfundsudviklingen disse år, som magtfulde diskurser 'ideé force' som har til formål at naturalisere forestillinger om, hvordan verden hænger sammen og hvad vi alle sammen har brug for (Bourdieu 1998, 
34). Det er diskurser om globalisering, fleksibilitet, forandringsparathed, professionalisme, 7 konkurrencedygtighed og performance, der siver ind i alle brancher. De bliver en slags overgribende diskurser, som lever i offentligheden som selvfølgeligheder, der ikke sættes spørgsmål ved, og som disciplinerer både individer og grupper. Man kunne også betegne dem som 'ledsagere' i skabelsen af nye socialkarakterer.

Der er tale om forandringer af både materiel og symbolsk karakter (Bovbjerg 2001, Hochschild 1997, Bourdieu 1998, Tynnel 2002). Der er ting, man i dag kan tale om og vise i det offentlige rum, som tidligere var omgivet af tabuisering og social kontrol. Områder som før blev forbundet med f.eks. familie, følelsesliv og intimsfæren findes nu i den brede offentlighed til skue for enhver. Det kan næsten synes som om grænserne for, hvilke oplevelser og erfaringer der bringes ind i det offentlige felt, er opløst. Men på en og samme tid installeres nye og mere subtile grænser, og disse har ofte at gøre med individets muligheder for at lykkes først og fremmest som deltager i samfundslivet gennem sin identitet som erhvervsaktiv. Kravene til arbejdskraften udtales i dag ikke primært som konkrete krav til bestemte arbejdsfunktioner men som overordnede beskrivelser i offentligheden af den succesfulde kompetente og omstillingsparate medarbejder. Bestemte brancher og arbejdslivstyper bliver dem, der primært tales om i det offentlige rum som representerede de alle organisationstyper i samfundet.

I mange organisationer tabuiseres konkrete konfliktområder udsprunget af interesseforskelle, de lever, kan man sige, i skjulte dagsordener, i bestemte rum, de individualiseres og gøres private ligesom bærerne af dem, stigmatiseres socialt. Sociale positioner som f.eks. 'offer' , 'skyld' og 'fiasko' bliver konsekvent undveget i konkrete dialoger, ligesom bestemte ord som konnoterer konflikt eller fortid undgås. ${ }^{8}$

Vores pointe er her, at specielt domine- rende diskurser i det offentlige rum omkring arbejde og arbejdsidentitet făr konsekvenser for de kønskontrakter som udfoldes i en organisation mellem medarbejderne. Et eksempel er diskursen om fleksibilitet, som fremstår som både kønsneutral og et krav til alle medarbejdere. Men fleksibiliteten har et kønnet ansigt, og det får betydning for forandringsprocesser i organisationer, ligesom det făr betydning for den interaktive forsker og dennes muligheder for at bidrage til forandringsprocesser i organisationer. Forandringsaktørerne har nemlig helt forskellig grad af mobilitet, alt efter hvor de befinder sig i organisationshierarkiet og hvad deres arbejdsfunktioner er (Gunnarsson 1998 og 2003, NUTEK 1997). Det er jo ofte sådan, at sekretærer og assistenter, dvs. kvindedominerede erhversgrupper, afkræves stabilitet, og ikke tillades at være fleksible og mobile på samme måde som mænd. Også i forhold til reproduktionen af en organisations kultur kan man se forskelle mellem den fleksibilitet og stabilitet, som forventes af kvinder og mænd, - på alle niveauer. Dette kan få stor betydning for deltagelsen, engagementet og rytmen i et interaktivt forskningsprojekt.

Brandth og Kvande peger i deres bog "Fleksible fedre" (2003) på at arbejdslivets krav om fleksibilitet er den største hindring for mænd som ønsker at være omsorgsfulde fædre. De spørger, hvor langt arbejdslivet i Skandinavien er nået med at forstå, at kønsrelationerne $\mathrm{i}$ forhold til forældreskab i hvert fald har forandret sig radikalt, således at familieliv i dag ser helt anderledes ud end for bare 20 år siden. Markedsorienteringen, i det som nu benævnes 'det grådige arbejdsliv', kolonialiserer hverdagslivet både strukturelt, materielt og symbolsk i en sådan grad, at arbejdslivets normativitet invaderer områder, hvor en tingsliggørelse af menneskelige relationer vil få eller allerede har fået katastrofale følger for vore samfund (Lorentzen 2003). Reproduktion og omsorg er under pres på nye måder og de 
kommende generationers sociale kapital truet.

Medarbejdere i mange organisationer lever i og med en lang rakke paradokser. Det, som i en situation beskrives som fleksibilitet og åbenhed overfor forandring, kan måske opleves som forandringstvang, ligesom diskursen om de frie, individuelle til og fravalg i forhold til egen livssituation, lever side om side med stramme, institutionelle rammer og deadlines. På den ene side taler man om mangfoldighed og respekt for forskelle som en meget positiv værdi på et arbejdssted. På den anden side er der tegn på en ensliggørelse f. eks i forhold til, hvilke egenskaber idealmedarbejderen skal besidde - egenskaber som fungerer som parametre i enhver jobsamtale. De paradokser jeg nævner her, beskrives som positive 'både-og-situationer' og ikke som modsætninger med negative effekter.

En vigtig drivkraft bag denne artikel har været ønsket om at styrke en kritisk stillingtagen til og brug af de 'hurraord', som omgiver diskussionerne om forskningens samfundsmæssige relevans, specielt i forhold til organisationsudvikling $\mathrm{i}$ erhvervslivet og som vores forskningfelt helt af sig selv, bliver påvirket af. Her tænker vi på ord som: dialog, flow, deltagelse, interaktivitet, fleksibilitet, synergi. Men de omtalte diskurser får ligeledes betydning for de relationer, som etableres mellem en organisations medlemmer og en gruppe forskere. Det er forandringer, som endnu er meget lidt udforskede og svære at takle, fordi også de er bundet op på normativitet.

Den poststrukturalistiske feministiske forsknings fokus på sproget og på denaturaliseringer kan kun inspirere til diskursive praksisser, som udfordrer tendenserne til reproduktion af disse i organisationsforskningen. Men, hvad hvis det er buzz-ordene, forskeren skal udtale, hvis en organisation skal få lyst til at koble sig på et forskningsprojekt? Hvad med demokratiet og dialogen hvis både forskere og deltagere fra organisationen hovedsageligt er optaget af at få egne individuelle strategier til at lykkes?

\section{FORANDRING SOM IDEKRAFT}

Men alle taler om forandring og om forandringens nødvendighed. Også "forandring" er en ideé force. Anders Fogh Jensen (2003) taler om forandringsfortællingen som en af de store fortællinger, der går gennem Europa lige nu. Han stiller et vigtigt spørgsmål: Er det fordi, der ingen forandring er, at forandring hele tiden sættes i tale? Eller er det den konstante forandringsuudholdelighed, der kalder på fortællingens stabiliserende kræfter? Han konkluderer, at forandring som positiv værdi er blevet indholdstom. Den er så utroværdig, at den ikke mere beruser mennesker, "men dog så troværdig at den får mennesket til at træde hurtigere i den kapitalitiske trædemølle med sin egen rundtossethed til følge".

Når forandring kommer på tale involveres deltagelse og dialog næsten automatisk. "Situationer der kræver at medarbejderne er med på at gøre noget andet end de plejer, kræver særlig kommunikation og ofte forhandling. Set fra et ledelsessynspunkt skal medarbejderne motiveres for xndringerne. Set fra et medarbejdersynspunkt kalder situationen i første omgang typisk på forsvar - alle ændringer er forbundet med usikkerhed, måske endda uvished" (Achen og Drxby 2004, 65-66). Achen og Drxby påpeger her en forskel mellem de forestillinger om, hvad en dialog omkring forandring forventes at medføre hos forskellige organisationsmedlemmer alt efter deres position i magthierarkiet. De vigtigste spørgsmål at holde sig for øje, når man inviterer til dialog, siger de, er "Hvad har vi gang i? Hvad er det for et rum, vi har omkring samtalen, hvor går dets grænser og hvem har autoriteten til at sætte dem? "(Achen og Dræby 2004, 71) Archen og Dræbye taler ud fra deres konsulenterfaringer, men de forhold de beskriver, gælder i ligeså høj 
grad de dialoger, man som interaktiv forsker bliver igangsætter af og ligner den nødvendige stillingtagen til forandring, vi før $i$ artiklen var inde på.

At arbejde med køn indebærer et arbejde for forandring, og man kunne spørge om der ikke er en klar sammenhæng mellem de modstandsreaktioner som efterhånden findes i mange organisationer hos medarbejderne på kravet om omstillingsparathed og forandringstvang og de reaktionsmåder kønsforskere møder hos både mænd og kvinder, når de præsenterer deres forskningsprojekter? For alle ved, at forandringer i kønsrelationer er træge og på mange ledder omkostningfyldte.

\section{UDFORDRINGER SOM KALDER PÅ HANDLINGER}

Som det nok nu vil fremstå rimeligt klart, mener vi, at bredere kontekstuelle betingelser som f.eks resultatorienteringen og det kortsigtede anvendelsesperspektiv gør det svært $i$ dag at lave deltagerorienteret, interaktiv og feministisk organisationsforskning. Hvilke bud har vi da selv på, hvor i skoven af udfordringer det giver bedst mening at tage fat?

Først og fremmest mener vi ikke, det giver mening at tage fat alene. Der findes en vigtig opgave $i$ at opbygge forpligtende og længerevarende forskningsfællesskaber omkring forskningsfeltet køn i organisationer, langt fra flygtige fleksible netværk, som er modellen i dag. Både interaktiv og feministisk forskning bliver bedre, hvis den produceres i og af fællesskaber, - gad vide om det ikke gælder al forskning.

Forskningsinstitutionernes legitimeringsog disciplineringsprocesser 'presser' den enkelte kritiske forsker til at indgå mange kompromisser og til fjerne sig fra at handle ud af de akademiske institutioner og ind $\mathrm{i}$ de udfordringer, der ligger $i$ at handle ind $i$ og forske fremad i organisationerne.

Som vi ser det, er et brud med de individualiserede forskningspraksisser en nødven- dighed også i forhold til de fremtidige udfordringer, som frem for alt forskere i den mere kritisk orienterede kønsforskning står overfor i dag. En af disse udfordringer er den "exccelenceformering", som sker på det videnskabelige felt både nationalt og internationalt. Hvis man botaniserer i skyggen af disse excellenceformationer, vil man opdage en stærk centralisering af magt og en forfordeling af positivitisk kundskabsproduktion. Udvalgte forskningsmiljøer gives magt til at definere, hvad der betragtes som 'rigtig forskning', 'forskning af høj kvalitet' og 'brugbar forskning'. En af de største udfordringer for kritiske feministiske forskere er antageligt at granske noget mere i disse tendenser og i resourcesetildelingerne, som følger disse.

De fund, som bliver resultatet, må bringes ind i det offentlige rum så som genstand for en samfundsmæssig diskussion om hvilken forskning, der er vigtig. I forskningsrapporten "Gender and Excellence in the making "(European Commission, EUR 21222 ) er et antal bidrag samlede som berører forskningsfeltet - gender and excellence. Man må stille spørgsmålet om excellenceforskning overhovedet giver mening, hvis ikke kønsdimensionen er et indarbejdet kvalitetskriterium. I den aktuelle danske diskussion om forskningens rolle har begrebet 'relevant forskning' oftest et positivistisk islæt, er anvendelses- og markedsorienteret og kortsigtet i sin tidshorisont. ${ }^{9}$ Magtkoncentrationer i bestemte forskningsmiljøer (ofte de i forvejen mest velhavende, da det kræver resourcer at skaffe eksterne midler) begrænser det kritiske forskningspotentiale, såvel indenfor excelenceforskningen som udenfor, og derfor kan man sige, at den øgede fokusering på excelenceforskning udfordrer såvel det kritiske aktionsforskningsprojekt som det feministiske. Her kunne arbejdet på at udvikle fælles fodslag mellem de to forskningstilgange være oplagt.

En anden oplagt sti at tage er at udfordre det interaktive perspektiv og organisa- 
tionsforskningen generelt med de nyskabende teori og metodeudviklinger, specielt den poststrukturalistiske feministiske forskning tilbyder. Denne feministiske position har på en omfattende og frugtbar måde tvunget en avanceret dekonstruktion af nuværende teorier og metoder, men har specielt resulteret $\mathrm{i}$ en fremvækst af nye ikke mindst metodiske tilgange (Adkins 2003 og 2003, Søndergård 1999, Staunæs 2004, Pedersen 2004). Metoder, som en interaktiv feministisk forsker som f.eks. Patricia Maguire (2001) påpeger, udfordrer aktionsforskningen, og tvinger den 'ned på jorden'med sine spørgsmål. Omvendt kunne man sige, at de mange spørgsmål vi har stillet, og som er inspirerede af nyere feministisk forskning gerne i stedet for kun at generere hovebrud, skulle generere lyst til at finde svar. En mulig forstyrrelse af vores egen måde at tænke på kunne være, at bevæge vor søgen efter svar fra selvrefleksion, hovedbrud og tanker over i aktion og krop. Er det ikke netop den interaktive traditions fokus på eksperimentet og praksis, som her ville kunne transformere de mange påtrængende og relevante spørgsmål til konkrete oplæg til eksperimenter og handlinger, man sammen med organisationsmedlemmerne kunne blive klogere af ved at afprøve? Hegnhøjs bevidste arbejde med metodisk at forholde sig til de dilemmaer hun møder i processen, er et sådant bud på, hvordan vi kvalificerer forskningen.

I erkendelse af forskersubjektets produktive status i forhold til kundskabsproduktionen er det ligeledes, når vi taler metoder, vigtigt at forholde sig til organisationsforskerens køn. Den mandlige overordning og den kvindelige underordning, måden kønnet gøres interaktivt og relationelt på, må udmøntes i bevidstgørende procesmetoder. Her kunne analyser af eksperimenter med meget konkrete bevidstgørende og dialogiske metoder være et godt bud.

Mødet med de organisatoriske felter og disses medlemmer er den største udfordring og den største kundskabskilde i inter- aktiv forskning. Men det betyder ikke, at forskeren ikke er en autoritet som kundskabsbærer i forhold til køn. Det feministiske forskningsfelt er i dag et omfattende felt, som indeholder viden om, hvordan køn udtrykkes historisk, strukturelt på forskellige samfundsmæssige niveauer f.eks. som her, hvordan køn gøres i organisationer. Feministiske forskere bliver derfor også vigtige kundskabsbærere af viden om køn. Kampen for at anerkende kvinder som kundskabsbærere i samfundet og indenfor akademia er lang og stenet, og det virker absurd hvis ikke denne kundskab skal på banen (Højgård og Søndergård 2004). Det virker absurd, at forskeren $\mathrm{i}$ "den hellige deltagelses navn" nedtoner sin rolle som bærer af viden, eftersom hun besidder en historisk genereret kundskab, som er en nødvendig forudsætning og dynamo i forandringsprocesserne.

Endelig ser vi en opgave i, at vi, som feministiske forskere i køn på organisationsområdet, styrker vores tilstedeværelse i den offentlige debat. Vxgtningen af kønssperspektivet som samfundsrelevant i den samfundsmæssige diskurs har ikke mindst i Norge og Sverige ledt til en stærk 'policy driven research' på kønsområdet, der som resultat har gjort, at der findes megen unik empiri på feltet. 'Køn' er i Sverige og Norge blevet et 'rethoric catchword' som nævnes, når der tales ligestilling og mainstreaming, selvom praktikken ofte udfolder sig anderledes end retorikken foreskriver. I Danmark lever kønsdiskurserne et noget mere konfliktfyldt liv, og forskningen på området har ikke haft samme gennemslagskraft i den offentlige debat. Men samfundets behov og måde at anvende feministiske forskningsresultater på i politiske spil på den ene side og det akademiske felts implicitte krav om en interessefri objektiv videnskab, på den anden, stiller ofte den feministiske forsker i en besværlig krydsild. Den store udfordring ligger $i$ at være både en aktiv del af samfundsmæssige forandringsproces og samtidig være i stand til at opret- 
holde en videnskabelig troværdighed i den eksisterende samfundsorden. Det offentlige rum kan ses som en arena, hvori en kritisk kønsforskning kan synliggøre samspillet mellem akademia og samfundspolitik. Tilstedeværelsen i offentlighen har tvunget den svenske feministiske kønsforskning til at tydeligegøre sine begreber og skabe nye metoder. Ikke mindst har samfundsdebatten igangsat vigtige refleksioner omkring, hvilke forhold midelklasseforskere reproducerer. Der ligger en opgave i at blive mere vant til at håndtere ekspertrollen samtidig med, at vi udfører et politisk forandringsarbejde, både $\mathrm{i}$ forhold til forskeroffentligheden og den bredere samfundsmæssige offentlighed. Specielt, hvis man i udgangspunktet problematiserer ekspertrollen og insisterer på et demokratisk perspektiv, hvor også andre stemmer end de priviligerede får adgang til offentligheden.

\section{NOTER}

1. Artiklen igennem vil der blive refereret til aktionsforskningen/den interaktive forskning som synonyme begreber - én videnskabsteoretisk position. Denne definition vil selvklart ikke stemme overens med aktionsforskeres forskellige opfattelser af, hvad aktionsforskning indebærer og med de forskellige tilgange som rent faktisk findes på feltet. For os er de centrale omdrejningpunkter i interaktiv/aktionsforskning spørgsmål om det epistemologiske ståsted, deltagelse, den fælles vidensproduktion, relationen subjekt-subjekt mellem forsker og praktiker samt de eksplicitte ønsker om social forandring.

2. Dorte Marie Søndergård bruger begrebet "kundskabstilbud" i stedet for forskningsresultater (Søndergård 1999).

3. Navnet er en anonymisering.

4. En afhængighedrelation som ofte etableres, og kan iagttages i aktionsforskningsprojekter.

5. Svensson (2002) skelner mellem fire grundtyper af relationer mellem forsker og deltager. Man kan i følge Svensson 'forske i', 'forske for', 'forske til fordel for', 'forske med'. Svensson positionerer sig selv i den interaktive forskning, 'forskning med'traditionen og han fremhæver, at denne position indebærer en accept af forskelle mellem forskersubjekt og praktikere.

6. Vi bruger som tidligere nævnt begreberne interaktiv forskning/aktionsforskning meget pragmatisk. For os er begrebsdefinitionen og distinktionerne melllem de mange aktionsforskningsretning$\mathrm{er} /$ trationer mindre vigtige end den nødvendige og selvrefleksive og kritiske eksplicitering af forskersubjektets bevægelige positioner i hans/hendes egen forskningspraksis med andre praktikere, et forhold som gør Svenssons model meget praktisk at tænke med.

7. I 90'ernes Danmark var der et mærkbart fokus på hvordan en korrekt forholdemåde i en arbejdssituation burde være. Ordet "professionel" havde i den forbindelse en meget vigtig funktion som disciplineringsdiskurs.

8. I Danmark sker det f.eks. med ord som feminist. 9. Fra forskning til faktura, en titel på den danske regerings forskningsudspil, er en afspejling af denne tankegang.

\section{LITTERATUR}

- Achen, Benedikte og Inger Dræby (2004): "Vi kan ikke bare snakke os til det - om dialogens begrænsninger i det organisatoriske liv i Helle Alrø og Marianne Kristiansen (red): Dialog og magt $i$ organisationer Serie om interpersonel kommunikation i organisationer nr.8 Ålborg Universitetsforlag, Aalborg.

- Acker, Joan (1999): “Gender and Organizations", in Saltzman Chafetz and J. Kluwer:Handbook of the Sociology of Gender. Academic/Plenum Publishers, New York.

- Acker, Joan (1998): The Future of 'Gender and Organizations' : Connections and Boundaries. Paper for plenary talk at the Gender, Work and Organization Conference, Manchester, January 1998.

- Adkins, Lisa (2002): Revisions: Gender and Sexuality in Late Modernity: Open University Pres. Buckingham

- Adkins, Lisa (2003) Reflexity - Freedom or Habit of Gender? In Theory, Culture and Society 2003, Vol.20 (6): 21-42.

- Brandth, Berit og Elin Kvande (2003): Fleksible fedre, Universitetsforlaget, Oslo.

- Bovbjerg, Kirsten Marie (2001): Følsombedens Etiki. Forlaget Hovedland, Højbjerg.

- Bourdieu Pierre (1998): Acts of resistance - against the new myths of our time. Polity Press, Cambrigde.

· Bradbury Hilary and Peter Reason. (2001): “In- 
troduction: Inquiry and Participation in Search of a World Worthy of Human Aspiration" in "Handbook of Action Research. Sage, London

· Collinson, David and Jeff Hearn (1994):"Naming Men as Men: Implications for Work, Organization and Management", in Gender, Work and Organization, vol. 1, no. 1 .

· Davies, Karen (1999): "Närhet och gränsdragning - att nå andra sorters kunskaper genom deltagande observation", i Mer än kalla fakta - Kvalitativ forskning $i$ praktiken, Studentlitteratur. - Eduards, Maud (2002): Fõrbuden handling. Om kvinnors organisering og feministisk teori. Liber, Malmø.

- European Commission, (2004) Gender and Excellence in the Making, Directorate-General for Research, EUR 21222.

· Gemzöe, Lena (2002): Feminism, Bilda Förlag, Stockholm.

- Gherardi, Silvia (1995): "Køn - noget vi tænker, noget vi gør i vores daglige liv i organisationer" i Elisabeth Flensted-Jensen m.fl.: Kon og kultur $i$ organisationer, Odense universitetsforlag, Odense, 11-37.

- Gunnarsson, Ewa (1998): "Distansarbete ur ett jämställdhetsperspektiv", i Distansarbetsutredningen, bilaga 4, SOU 1998:15.

- Gunnarsson, Ewa (2003): "Disguised in the shadows of symbol discourses - an attempt at developing a multiple tool analysis approach among 'nomads' and 'groundeds' in flexible an,d networkoriented organisations," in . Eds, Gunnarsson, E, Andersson, S, Vänje Rosell, A, Lehto, A and Salminen-Karlsson: Where Have All the Structures Gone-Doing Gender in Organisations, Examples from Finland, Norway and Sweden. Report serie at the Center for Women's studies, Stockholms University nr.33, Stockholm.

- Gunnarsson, Ewa, Andersson, Susanne, Vänje Rosell, Annika, Lehto, Arja and Salminen-Karlsson, Minna (2003): Where Have All the Structures Gone - Doing Gender in Organisations, Examples from Finland, Norway and Sweden. Report serie at the Center for Women's studies, Stockholms University nr.33, 2003, Stockholm.

- Gunnarsson, Ewa, Andersson, Susanne och Westberg, Hanna (1998): Känsla och regelverk $i$ balans Arbetslivsinstitutet/Folksam, Stockholm.

- Gunnarsson Ewa og Gunnel Forsberg (1985):

Kvinnokampanjen - en probleminventering, Arbetsmarknadsdepartementet, Jämställdhetssekretariatet/Arbetslivscentrum, Stockholm.

- Haavind Hanne red. (2000): Kjonn og fortolkende metode. Metodiske muligheder $i$ kvalitativ forskning. Gyldendal akademisk, Oslo.
· Harding, Sandra (1992): "Subjectivity, Experience and Knowledge: An Epistemology from /for Rainbow Coalition Politics," in Development and Change Vol.23 no 3, 175-193.

- Harding, Sandra red. (2004): The Feminist Standpoint Theory Reader. Intellectual and Political Controversies, Routledge, New York and London.

- Hegnhøj, Rikke Randorff (2004): Mellem konsensus og krise. En undersøgelse af kønnede forandringsmuligheder $i$ organisationer, speciale Kommunikation RUC, Roskilde.

- Hochscild, Arlie Russel (1997): The time bind. Metropolitan books, N.Y.

- Højgård, Lis og Dorte Marie Søndergaard red. (2003):Akademisk tilblivelse - Akademia og dens kønnede befolkning. Akademisk Forlag, København.

- Jensen, Anders Fogh (2003): "Forandringens trædemølle" i Univesitetsavisen 17. Københavns Universitet.

- Kvale, Steiner (1992): "What is anthropological research? An interview with Jean Lave." Nyhedsbrev, Center for Kvalitativ Metodeudvikling. Psykologisk institut Århus universitet, Århus, 3-10.

- Kvande, Elin (2003): "Doing Gender in Organizations", in Where Have All the Structures GoneDoing Gender in Organisations, Examples from Finland, Norway and Sweden. Eds, Gunnarsson, E, Andersson, S, Vänje Rosell, A, Lehto, A and Salminen-Karlsson, M, Report serie at the Center for Women's studies, Stockholms University nr.33, 2003, Stockholm.

- Korvajärvi, Päivi (1998): Gendering Dynamics in White-Collar Work Organizations Acta Universitatis Tamperensis 600, University of Tampere, Tampere.

- Lorentzen, Jørgen (2003): Fleksible fedre og det grådige arbejdsliv i www.kvinfo.dk/kulturzonen / - Maguire, Patricia (2001): "Uneven Ground: Feminism and Action Research", in Handbook of Action Research, eds. Peter Reason and Hilary Bradbury, SAGE, London.

- McNiff, Jean (2002): Action research principles and practice. Routledge/Falmer, London and New York.

- McNiff, Jean (2000): Action research in organisations, Routlegde. London/New York.

- Minnich, Elisabeth Kamarck (1990): Transforming Knowledge. Temple University Press, Philadelphia.

- Nussbaum, Martha C. (1995): Känslans skärpa, tankens inlevelse - Essäer om etik och politik. Symposion,Stockholm.

· NUTEK (!997): Virtually Free? - Gender, Work 
and Spatial Choice, eds, Gunnarsson, Ewa and Huws, Ursula, NUTEK rapport B 1997:7

- Pedersen, Christina Hee (2004) Billedet som anker. Metodisk inspiration til kvalitativ kommunikationsforskning i Nordicom Information, årgang 26, nr. 1 Gøteborg .

- Pedersen Christina Hee (2000): "Det farlige og befriende vi" Kvinder køn og forskning” nr. 4, 6167.

- Rasmussen, Bente:" Det nye arbeidslivet -fra stukturell mannsmakt til personlige valg" Paper til den 21 nordiske sociologikongress Reykjavik 15-17 augst 2002.11.22

- Schratz, M. og R. Walker (1995): Research as social change - new opportunities for qualitative research. Routledge. London.

- Skeggs, Beverley (1997): Att bli respektabel-konstruktioner av klass och kön. Bokförlaget Daidalos, Göteborg.

- Staunæs Dorthe (2004): Køn etnicitet og skoleliv.

Samfundslitteratur, Frederiksberg.

- Svensson Lennart, Göran Brulin, Per-Erik Ellström and Örjan Widegred (ed) (2002): Interaktiv forskning - för utveckling av teori och praktik. Work life in transition 7. Vetenskabelig Skriftserie från arbejdslivsinstituttet, Stockholm.

- Søndergaard Dorte Marie (1996): Tegnet på kroppen. Køn: Koder og konstruktioner blandt unge voksne $i$ akademia, Tusculanum forlag, København.

- Søndergård D.M (1999): Destabilising Discourse Analysis. approaches to poststructuralist empirical Research" Køn i den akademiske organisation, Arbejdspapir nr.7. København.

- Thurén, Britt-Marie (1996): “Om styrka, räckvidd och hierarki, samt andra genusteoretiska begrepp", Kvinnovetenskaplig Tidskrift, 3-4, 69-75. - Thurén, Britt-Marie (2003): Genusforskning Frågor, villkor och utmaningar, Vetenskapsrådet, Stockholm.

- Tynell Jesper (2002) "Det er min egen skyld"Nyliberale styringsrationaler indenfor human resource Management i Tidsskrift for arbejdslivsforskning, nr.2.

-West, Candace and Fenstermaker, Sarah (1995):" Doing Difference" in, Gender and Society, 1:2, 837

- Widerberg, Karin (2002): Kvalitativ forskning $i$ praktiken, Studentlitteratur, Lund

- Widerberg, Karin (1999): Alternative Methods Alternative Understandings: Exploring the Social and the Multiple 'I' through Memory-Work, Sosiologisk tidskrift $\mathrm{nr} 2$.

-Williams, Simon (2001): Emotion and Social Theory, Sage Publications, London.

\section{SUMMARY}

Later years of methodological and theoretical development within feminist research expands possible ways of approaching research on gender in organisations, whereas also questions of wider social and historical changes will influence the ways of understanding the gendered realities of organisations. The concern of the article is to present some of the current challenges and headacheproducing dilemmas of the interactive feminist researcher interested in strengthening gender research in organisations. It is suggested, that the there is an undiscovered potential in the inclusion of the researcher as a subject of knowledge production into the analysis of gender in organisation, and into the concrete dialogues with practitioners in organisations, and it is discussed how feminist approaches challenge the interactive approach by highlighting relations of gendered power structures and practices, being ignored by traditional action research. The authors discuss the political and academic contexts that limit the access to resources and time for participatory research, and show how wider societal development trends such as management discourses, changes in the relationship between public and private, understandings of politics, conflict and differences as broader contexts impose new challenges into both feminist and interactive organisational research. The article ends suggesting concrete actions at a methodological, professional and political level that would qualify organisational research on gender.

Christina Hee Pedersen, ph.d., lektor i organisationskommunikation Roskilde Universitetscenter.

Ewa Gunnarsson, docent på Arbejdslivsinstituttet i Stockholm 